\title{
PENGEMBANGAN MEDIA PEMBELAJARAN KOMIK DIGITAL BERBASIS SMARTPHONE UNTUK SISWA SEKOLAH DASAR
}

\author{
Favian Avila Syahmi, Saida Ulfa, Susilaningsih \\ Teknologi Pendidikan, Fakultas Ilmu Pendidikan, Universitas Negeri Malang. \\ Jl. Semarang No.5, Malang, 65145, Indonesia. \\ favianavila80@gmail.com
}

\section{Article History}

Received: 18 Maret 2021, Accepted: 11 April 2021, Published: 20 Februari 2022

\begin{abstract}
Abstrak
Penelitian dan pengembangan ini bertujuan untuk menghasilkan suatu produk yang berupa media pembelajaran komik digital sebagai suatu inovasi pembelajaran pada mata pelajaran IPS materi runtuhnya kerajaan Kediri. Penelitian Research and Development $(R \& D)$ menggunakan metode Borg and Gall yang tahapannya sesuai dengan kebutuhan pengembang dan sesuai dengan produk (pencarian dan pengumpulan data; perencanaan, mengembangkan produk, uji kelayakan produk, revisi hasil uji kelayakan produk, uji coba lapangan dan penyempurnaan produk). Didalam pembelajaran komik digital ini menjadi pelengkap dalam pembelajaran IPS, yang berarti media ditujukan untuk melengkapi materi pembelajaran yang diterima siswa didalam kelas. Media ini penggunaanya dalam pembelajaran harus menggunakan smartphone. Kelayakan produk yang telah dilakukan oleh para ahli dan siswa mendapatkan hasil tanggapan positif. Sehingga dapat dikatakan bahwa media komik digital materi runtuhnya kerajaan kediri ini layak digunakan didalam pembelajaran dikelas. Media ini memberikan kemudahan, kemenarikan, dan motivasi dalam aktivitas belajar mengajar, sehingga siswa rasa ingin belajar terhadap pembelajaran IPS akan meningkat.
\end{abstract}

Kata kunci: Smartphone; Komik Digital; Runtuhnya Kerajaan Kediri

\begin{abstract}
This research and development aims to produce a product in the form of digital comic learning media as a learning innovation in social studies subjects, the material for the collapse of the kingdom of Kediri. Research Research and Development $(R \& D)$ using the Borg and Gall stages according to the needs of developers and in accordance with the product (search and data collection; planning, developing products, test the feasibility of the product, the revision of the results of the feasibility test products, field testing and refinement of the product). In learning digital comics, this is a complement to social studies learning, which means that the media is intended to complement the learning material that students receive in the classroom. Use of this media in learning must use a smartphone. The feasibility of the product that has been carried out by experts and students has received a positive response. So it can be said that the digital comic media material for the fall of the Kediri kingdom is suitable for use in classroom learning. This media provides convenience, attractiveness, and motivation in teaching and learning activities, so that students' desire to learn about social studies learning will increase.
\end{abstract}

Keyword: Smartphone; Digital Comic; The fall of the Kediri Kingdom 


\section{PENDAHULUAN}

Media pembelajaran merupakan alat yang diperlukan pendidik untuk perencanaan dan penalahan dalam penerapan di pembelajaran. Pengembangan media disesuaikan dengan materi yang dipelajari siswa. Dengan hal - hal tersebut, siswa dapat paham akan materi yang diajar secara utuh juga menghilangkan tingkah laku yang negatif pada aktivitas belajar tersebut. Dalam pendidikan media merupakan alat bantu yang memberikan informasi untuk tercapainya tujuan pembelajaran (Nurmadiah, 2016). Media merupakan salah satu penyokong dalam suatu kegiatan belajar mengajar (Nurrita, 2018).

Kegiatan belajar mengajar adalah kegiatan belajar yang dilakukan untuk menghasilkan prestasi agar sesuai dengan tujuan dilakukannya kegiatan belajar mengajar (Suwardi \& Farnisa, 2018). Akan banyak siswa yang mengalami kesulitan dalam memperoleh tujuan dari kegiatan belajar mengajar tersebut. Proses pembelajaran merupakan aktivitas yang didalamnya tampak interaksi antara guru-siswa dan komunikasi yang saling timbal balik yang berlangsung dalam suasana edukatif guna tercapainya poin pembelajaran (Nugraha, 2018). Peran yang dimiliki guru sangat penting dalam mengatasi suatu permasalahan yang dialami oleh siswa tersebut. Guru dalam kegiatan belajar mengajar juga membutuhkan alat bantu untuk mengajar berupa media pembelajaran (Azman et al., 2014), karena beberapa materi juga tidak cukup untuk sekedar hanya lisan saja, namun juga perlu dihadirkan materi secara visual.

Seiring berjalannya waktu arus teknologi semakain maju dan berkembang pesat terutama pada smartphone, perangkat ini hampir dimiliki oleh semua siswa di Indonesia, karena terjangkau untuk semua(Amalia et al., 2020). Sehingga guru dituntut untuk lebih kreatif dalam memecahkan suatu masalah pendidikan. Pada suatu kegiatan belajar diminta siswa mampu menggunakan kemampuan indranya dengan baik atas media pembelajaran tersebut. Karena dalam Kegiatan belajar siswa terkadang kemampuan berfikir siswa kurang didorong.

Dalam pembelajaran yang ada di Indonesia terdapat mata pelajaran IPS. IPS merupakan mata pelajaran di Sekolah Dasar yang memuat tentang materi geografi, sosiologi, ekonomi dan sejarah (Afandi, 2011). IPS sangat penting untuk diajarkan dikarenakan salah satu mata pelajaran wajib ditingkat SD (Putri \& Citra, 2019). Salah satu bidang yang diberikan yang diberikan pada waktu sekolah dasar adalah IPS agar mendukung tercapainya tujuan pendidikan nasional Indonesia (Siska, 2016). Tujuan diberikannya mata pelajaran IPS sejak bangku sekolah dasar adalah agar siswa mampu menerapkan pengetahuan dan keterampilan dasar yang berguna bagi dirinya dikehidupan sehari - hari. IPS adalah bahan kajian yang teratur yang disederhanakan dari keterampilan sejarah, geografi, sosiologi, antropologi dan ekonomi (Ratnawati, 2016). Akan tetapi, selama ini mata pelejaran IPS dianggap sepele oleh sebagian orang, dan mengkatan bahwa IPS mata pelajaran yang dianggap membosankan dan kebanyakan materi yang terdapat pada mata pelajaran IPS berupa hafalan, dan hal itu menjadi masalah bagi mata pelajaran IPS.

Pada mata pelajaran IPS terdapat materi sejarah tentang tema runtuhnya kerajaan kediri. Dipembelajaran sejarah tentang tema runtuhnya kerajaan kediri harus dapat benar - benar memahami sejarah tersebut agar tercapainya tujuan dan nilai - nilai dari sejarah tersebut. Dengan belajarnya sejarah siswa diharapkan menjadi pribadi yang bijak, arif dan bijaksana, karena didalam sejarah siswa juga dapat memahami dan menghayati peristiwa sejarah tersebut agar nilai - nilai dan manfaat sejarahnya dapat dipetik (Afiqoh et al., 2018). Sehingga, perlu adanya alat bantu berupa media pembalajaran yang efektif sebagai perantara komunikasi dalam kegiatan pembelajaran (Sihkabuden, 2011).

Media yang berisikan suatu cerita bergambar dengan tokoh karakter yang menyajikan informasi adalah Komik. Komik adalah bentuk media komunikasi visual untuk menyampaikan 
informasi secara popular dan mudah dipahami (Tresnawati et al., 2016). Komik adalah media yang digunakan guru saat aktivitas belajar menyimpulkan isi cerita. Karena komik dalam aktivitas belajar mengajar memiliki peran serta tinggi terhadap daya ingat dan memoring jangka panjang. Media komik memiliki sifat yang transparan dan mudah dipahami dan komik juga mempunyai fungsi informasi dan edukasi. Panel yang dimiliki komik merupakan storyboard yang diceritakan dari dan dibaca dari kiri ke kanan. (Patricia, 2018). Komik juga menggambarkan suatu kejadian yang didalamnya terdapat satu tokoh atau lebih dalam rangkaian waktu terbatas, sehingga komik dapat meningkatkan imajinasi dan kreatifitas siswa. Dialog yang ditampilkan dalam suatu komik biasanya dilingkari di dalam balon yang dikeluarkan dari mulut suatu tokoh sehingga terlihat seakan berbicara. Media yang unik ini berupa komik, karena didalam komik terdapat penggabungan teks dan gambar dalam bentuk yang kreatif. Karena itu media ini digemari dalam berbagai usia karena kelebihan yang dimiliki oleh komik ini yaitu mudah dimengerti (Mediawati, 2011). Komik adalah media yang berguna karena tidak membutuhkan kalimat atau paragraph yang panjang untuk menceritakan sebuah cerita dan tokoh ddalam ceritak komik hanya membutuhkan beberapa kata untuk mengungkapkan suatu plot dengan demikian, siswa dapat belajar bagaimana menggunakan kosakata dan dialog baru dalam berbagai situasi melalui media ini.(Chen et al., 2018)

Dari beberapa penjelasan diatas maka dikembangkanlah produk media pembelajaran berupa komik digital. Karena komik dipilih sebagai produk yang dikembangkan karena komik berisi gambar - gambar dengan isi bacaan yang ringan. Komik digital merupakan suatu bentuk cerita dengan tokoh - tokoh tertentu yang disajikan dalam bentuk gambar dan penyajiannya menggunakan alat elektronik. Komik digital dalam suatu pembelajaran berfungsi sebagai komplemen atau pelengkap. Media disebut sebagai komplemen bilamana media itu dijadikan sebagai pelengkap pada pembelajaran (Azmi, 2016). Komik Digital ini dikembangkan melalui software Clip Studio Paint yang tersedia di dalam komputer dan laptop dan hasil format berupa pdf. Komik Digital ini menarik karena cerita dan dialog antar tokoh akan dikemas dalam bentuk komik yang dioperasikan menggunakan smartphone, sehingga pembaca akan merasa nyaman dan mudah untuk digunakan karena smartphone hampir dimiliki oleh semua orang. Beberapa ulasan tentang mobile learning telah dilakukan selama sepuluh tahun terakhir. Masing - masing telah menyumbangkan informasi penting bagi para siswa untuk lebih memahami penggunaan perangkat seluler dalam pendidikan (Crompton \& Burke, 2018). Karena pembelajaran ini bisa dilakukan dimana saja maka komik digital meruapakan pembelajaran mobile learning (Martha et al., 2018).

Pengembangan ini bertujuan untuk menghasilkan komik digital mata pelajaran IPS materi sejarah yang bertema runtuhnya kerajaan Kediri. Dengan adanya komik digital ini diharapkan siswa memiliki rasa ketertarikan, motivasi dan kemudahan dalam pembelajaran. Dengan tujuan siswa dilatih kreatif dan inovatif dan siswa dilatih guna memahami nilai hidup yang baik dan terpuji cocok dengan tujuan IPS.

\section{METODE}

Penelitian dan pengembangan ini menggunakan metode research and devlopement (R\&D). Menurut Sugiyono (2014) bahwa metode penelitian ini adalah dihasilkannya produk dan keefektifan dari produk ini diuji (Ashri \& Hasanah, 2015). Dikembangkannya produk ini bertujuan untuk menghasilkan komik digital berbasis smartphone. Model pengembangan produk yang digunakan, mengarah pada model Borg and Gall (2003) yang mengutarakan bahwa dalam penelitian dan pengembangan, tahapan - tahapannya ialah suatu siklus yang didalamnya terdapat kajian terhadap berbagai temuan penelitian yang ada dilapangan dan berhubungan dengan produk yang akan dikembangan. Borg \& Gall menngemukakan bahwa prosedur penelitian pengembangan 
ada 10 langkah, yaitu: Research and information collecting (pencarian dan pengumpulan data), Planning (perencanaan), Develop preliminary form of product (mengembangkan bentuk produk awal), Preliminary field testing (uji coba lapangan awal), Main product revision (revisi hasil uji coba lapangan awal), Main field testing (uji coba lapangan utama), Operational product revision (revisi produk operasional), Operational field testing (uji coba lapangan operasional), Final product revision (penyempurnaan produk akhir), dan Dissemination and implementation (diseminasi dan implementasi).

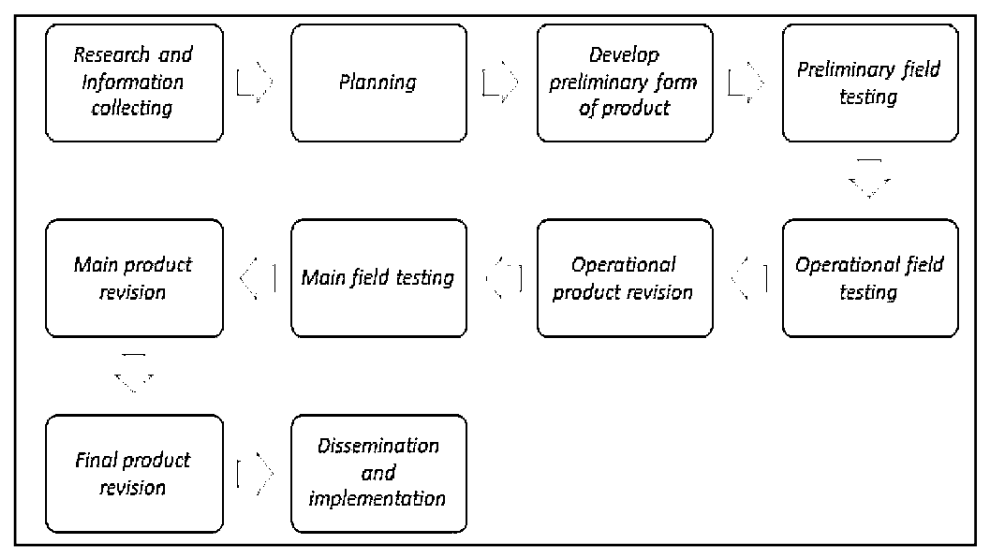

Gambar 1. Model R\&D Borg and Gall (2003)

Mengingat adanya keterbatasan dengan adanya kendala pandemi Covid-19, penerapan langkah-langkah tersebut dimodifikasi dengan kebutuhan pengembang. Penyesuaian ini tetap mengacu terhadap ketentuan pengembangan produk yang pasti dengan langkah yang sudah dijelaskan oleh Borg \& Gall, penyesuaian ini meliputi 7 pokok tahapan, yaitu: Pencarian dan Pengumpulan Data,Perencanaan, Mengembangkan Produk, Uji Kelayakan Produk, Revisi Hasil Uji Kelayakan Produk, Uji Coba Lapangan, Penyempurnaan Produk Akhir.

Pengembangan komik digital materi runtuhnya kerajaan Kediri disesuaikan dengan kebutuhan siswa berdasarkan latar belakang masalah yang ada, agar tingkat kelayakan dapat diketahui maka uji coba dilaksanakan kepada ahli media dan ahli materi. Ahli media adalah seorang dosen Teknologi Pendidikan di Universitas Negeri Malang dan Ahli materi adalah seorang guru SDN Bangah Gedangan, Sidoarjo. Produk yang dihasilkan juga diujicobakan kepada siswa untuk mengetahui kemudahan dalam penggunaan komik digital tersebut. Responden adalah siswa kelas IV SDN Bangah Gedangan, Sidoarjo berjumlah 3 orang siswa. Data yang dihasilkan dalam pembuatan produk komik digital ini adalah membagikan angket berisi pernyataan dan terdapat saran dan komentar untuk diujinya kelayakan oleh para ahli. Dilakukannya sampai tahap penyempurnaan produk akhir dalam penelitian ini.

Teknik analisis data dari para ahli dan siswa menggunakan hasil skor angket yang telah diperoleh, tanggapan saran dan komentar dari para ahli telah diolah. Diolahnya data memberikan uraian yang jelas dapat diambil kesimpulan kelayakan media. Dikatakan layak dan bisa digunakan dalam kegiatan belajar mengajar apabila mendapatkan respon positif.

\section{HASIL}

Pengembangan ini telah dihasilkannya produk berupa beberapa tampilan dari komik digital materi runtuhnya kerajaan Kediri pada gambar 2. 


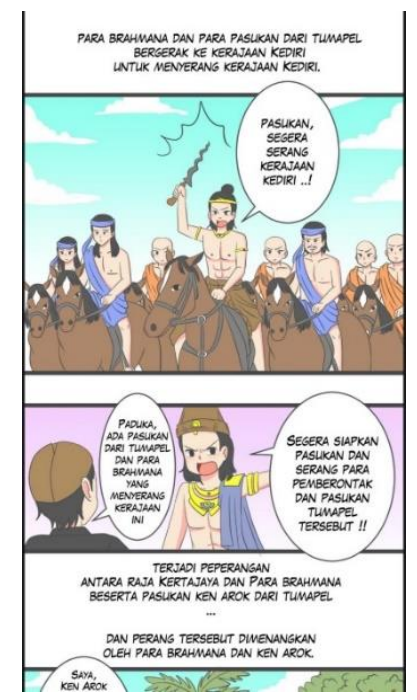

\section{Gambar 2. Tampilan komik digital}

Pada penelitian ini dilakukan Uji kelayakan produk dilakukan oleh para ahli yang mempunyai keahlian dalam bidang yang sesuai untuk memberikan suatu penilain terhadap produk yang dikembangkan. Kemudian setelah dilakukannya penilaian terhadap produk tersebut dilanjutkannya dengan diujicobakan kepada siswa untuk mengetahui keberhasilan tujuan dari pengembangan produk tersebut.

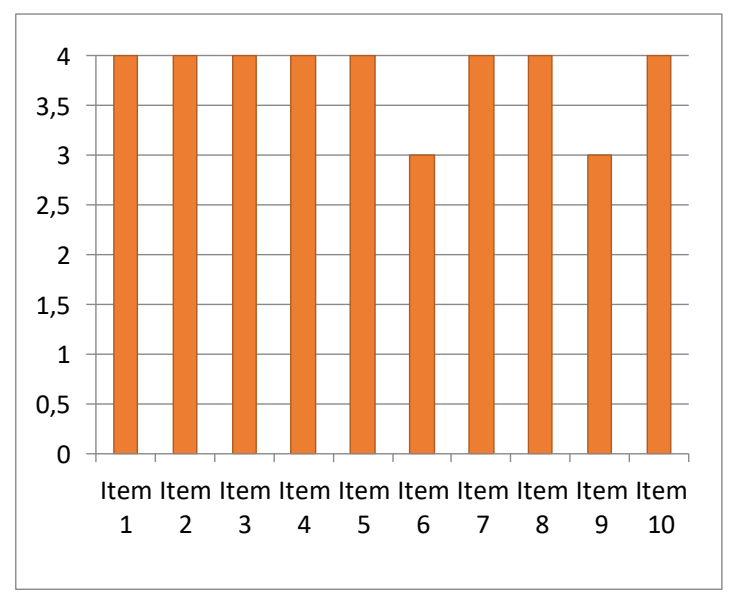

\section{Grafik 1. Hasil Tanggapan Angket Ahli Media}

Pada grafik 1 ditampilkan hasil respon yang telah diperoleh dari ahli media. Dengan hasil dari persentase tanggapan positif sebesar 100\%, dengan persentase tanggapan SS sebesar 80\%, sedangkan persentase tanggapan S sebesar 20\%. Dari analisis pada tabel tersebut juga mendapatkan mean 3,8, median 4, modus 4. Sehingga dari data tersebut dapat dikatakan bahwa media layak digunakan dalam aktivitas belajar mengajar. 




Grafik 2. Hasil Tanggapan Angket Ahli Materi

Pada grafik 2 ditampilkan hasil respon yang telah diperoleh dari ahli materi. Dengan hasil dari persentase tanggapan positif sebesar 100\%, dengan persentase tanggapan SS sebesar 60\%, sedangkan persentase tanggapan S sebesar 40\%. Dari analisis pada tabel tersebut juga mendapatkan mean 3,6, median 4, modus 4. Sehingga dari data tersebut dapat dikatakan bahwa media layak digunakan dalam aktivitas belajar mengajar.

Pada Tabel 1. Hasil uji coba lapangan dilakukan kepada satu kelas yang terdiri 3 siswa SD kelas IV SDN Bangah Gedangan, Sidoarjo. Hasil uji coba lapangan media pembelajaran komik digital pada pembelajaran IPS pada materi runtuhnya kerajaan Kediri menghasilkan rata - rata sebesar 3,8 dari rata - rata maks sebesar 4,0 atau sebesar 96\% dari $100 \%$. Sehingga dapat disimpulkan bahwa media komik digital layak digunakan dalam proses pembelajaran. Walaupun beberapa siswa juga memberikan tanggapan negatif pada angket.

Tabel 1. Hasil Tanggapan Siswa

\begin{tabular}{|c|c|c|c|c|c|}
\hline \multirow{2}{*}{ Pernyataan } & \multicolumn{3}{|c|}{ Jumlah Pemilih } & \multirow{2}{*}{ Rata - rata } & \multirow{2}{*}{ Persentase } \\
\hline & SS & $\mathrm{S}$ & KS & & \\
\hline Teks atau tulisan mudah dibaca & 3 & & & 4,00 & $100 \%$ \\
\hline Komik mudah digunakan & 2 & & 1 & 3,33 & $82,5 \%$ \\
\hline Bahasa mudah dipahami & 3 & & & 4,00 & $100 \%$ \\
\hline Alur cerita mudah dipahami & 3 & & & 4,00 & $100 \%$ \\
\hline Cover menarik dan sesuai dengan cerita & & 3 & & 3,00 & $75 \%$ \\
\hline Gambar tokoh karakter jelas dan menarik & 3 & & & 4,00 & $100 \%$ \\
\hline Tampilan sederhana dan menarik & 3 & & & 4,00 & $100 \%$ \\
\hline Antusias dalam mengikuti kegiatan pembelajaran & 3 & & & 4,00 & $100 \%$ \\
\hline $\begin{array}{l}\text { Menimbulkan rasa keingintahuan belajar IPS secara } \\
\text { mendalam }\end{array}$ & 3 & & & 4,00 & $100 \%$ \\
\hline Menggunakan media secara berulang-ulang & 3 & & & 4,00 & $100 \%$ \\
\hline Total & 26 & 3 & 1 & 3,8 & $96 \%$ \\
\hline
\end{tabular}

\section{PEMBAHASAN}

Media komik digital ini dikembangkan melalui beberapa tahapan yang mengarah pada model Borg and Gall yang telah dimodifikasi menjadi 7 tahapan dikarenakan adanya keterbatasan pengembang yaitu pandemi Covid - 19. Uji kelayakan produk ini mendapatkan hasil tanggapan dari para ahli media dan ahli materi dan juga sudah diujicobakan di lapangan yang melibatkan dari 3 orang siswa SD kelas IV SDN Bangah Gedangan, Sidoarjo. Pada ahli media terdapat 2 aspek kemudahan dan kemenarikan. Sedangkan dalam aspek kemudahan membahasas tentang bahasa yang mudah yang jelas mudah dipahami, penggunaan kalimat yang efektif, tata letak panel komik sederhana dan mudah, mudah operasikannya komik digital dan bahasa yang digunakan komunikatif dalam penggunaan komik digital tersebut. Sedangkan pada aspek kemenarikan membahas tentang 
pengguna dapat berinteraksi dengan penulis dan pembaca lainnya, alur cerita yang menarik, keserasian antara tampilan media dengan teks dan gambar dan cover judul menarik dan sesuai dengan cerita. Aspek - aspek yang tedapat dalam angket tersebut berisikan 10 butir item pernyataan. Aspek kemudahan berisikan 5 butir pernyataan dan aspek kemenarikan berisikan 5 butir pernyataan. Hasil dari ujicoba kelayakan produk tersebut yang dilakukan oleh ahli media mendapat tanggapan yang positif dengan persentase $100 \%$ dan layak untuk digunakan dalam proses pembelajaran tanpa revisi dengan saran dan komentar secara umum sudah baik, optimalkan cover dengan melengkapi credit title seperti identitas pengembang, identitas pembuat naskah dan crew yang membuat komik tersebut.

Kemudian dilanjutkan dengan menguji kelayakan media komik digital oleh ahli materi. Uji kelayakan komik digital ini dilaksanakan guna memperoleh kelayakan media, terkait dengan isi materi pembelajaran dan tujuan pembelajaran yaitu runtuhnya kerajaan Kediri. Didalam angket ahli materi terdapat 4 aspek pernyataan yaitu aspek identitas yang membahas tentang identitas mata pelajaran media, aspek relevensi berisikan tentang kesusaian antara SK, KD, indikator tujuan pembelajaran dengan materi yang disajikan dalam media pembelajaran, aspek kemudahan yang membahas tentang cerita dan bahasa mudah dipahami oleh siswa, dan aspek kemenarikan yang membahas tentang karakter tokoh dan peristiwa dalam cerita sangat menarik. Aspek aspek tersebut berisikan 10 butir item pernyataan yang terdiri dari 2 butir aspek identitas, 3 aspek relevansi, 2 aspek kemudahan, dan 3 aspek kemenarikan. Hasil dari uji kelayakan produk yang telah dujikan ke ahli materi mendapatkan tanggapan positif dengan persentase $100 \%$ dan layak digunakan dalam proses pembelajaran tanpa revisi dengan saran dan komentar secara keseluruhan sudah baik, gambar komik juga menarik akan tetapi pesan secara moral dari ceritanya hendaknya ditampilkan dalam komik tersebut.

Selanjutnya dilakukan ujicoba lapangan yang melibatkan 3 siswa SD kelas IV SDN Bangah Gedangan, Sidoarjo. Ujicoba lapangan ini dilakukan juga untuk memperoleh kelayakan media. Terdapat 3 aspek pernyataan yaitu aspek kemudahan, aspek kemenarikan, dan aspek motivasi. Aspek kemudahan dibahasnya kemudahan belajar dengan menggunakan komik digital, aspek kemenarikan dibahasnya gambar dan tampilan komik digital menarik dan sederhana, dan aspek motivasi dibahasnya menibulkan motivasi terhadap siswa saat belajar setelah digunakannya media komik digital tersebut.. Seperti yang terdapat pada gambar 6, aspek kemudahan terhadap pernyataan nomor 1-4, aspek kemenarikan terhadap pernyataan nomor 5-7, dan aspek motivasi terdapat pernyataan nomor 8-10, sehingga keseluruhan butir item pada angket siswa tersebut berjumalah 10. Ujicoba lapangan ini mendapatkan hasil keseluruhan 3,8 dari rata - rata maks yang diharapkan 4,0 atau mendapatkan persentase sebesar $96 \%$ dari $100 \%$.

Setelah melalui uji kelayakan dapat diketahui bahwa media ini sudah layak untuk digunakan dalam pembelajaran. Tetapi media ini juga masih memiliki kekurangan seperti dalam membuka komik digital tersebut didalam smartphone ada beberapa gambar yang tidak didalam panelnya sehingga penyajian materi yang ada didalam komik digital tersebut kurang detail. Pentingnya penyajian materi secara terpadu sehingga siswa dapat mencapai target (Herijanto, 2012). IPS merupakan salah satu mata pelajaran wajib yang diberikan sejak SD, melalui mata pelajaran IPS siswa diarahkan menjadi warga negara Indonesia yang bertanggung jawab dan cinta damai. IPS layak mendapatkan ruang di sekolah dasar, selain mempelajari konten yang akan mendukung dalam pembelajaran, siswa mendapatkan kebiasaan berfikir kritis dan keterampilan literasi disiplin. (Hutton \& Hembacher, 2017)

Dalam pembelajaran mata pelajaran IPS materi runtuhnya kerajaan Kediri menyiapkan media selain buku paket agar dapat menarik perhatian siswa, memberikan kemudahan dalam proses 
pembelajaran dan meningkatkan motivasi siswa. Media pembelajaran harus dapat memberikan pengelaman yang menyenangkan dan dapat memenuhi kebutuhan untuk dapat meningkatkan motivasi belajar siswa. (Ratnaningsih \& Nastiti, 2018). Hal ini ditujukkan dapat menumbuhkan aktivitas belajar mengajar dalam penggunaan komik (Ntobuo et al., 2018). Pengalaman yang menyenangkan dapat terwujud dengan menggunakan media yang dikembangkan ini yaitu komik digital sebagai media pembelajaran materi runtuhnya kerajaan Kediri di SD. Dipembelajaran ini mengulang isi cerita dengan kosa kata sendiri sesuai tujuan pembelajaran. Komik digital ini berbentuk format digital berbasis elektronik yang menampilkan gambar yang menarik dan mempermudah pembaca dalam mengikuti alur cerita dan penyampaiannya dilakukan melalui smartphone menggunakan format .pdf (Sukmanasa et al., 2017). Panel - panel tersebut yang dimiliki komik saling berhubungan satu antar lainnya seperti jaringan, dengan munculnya panel tersebut dapat menunjukan pendekatan timeframing yang dapat mengubah layout dan isi dari panel tersebut (Yunanto \& Heryanto, 2021). Komik digital ini berisi tentang runtuhnya kerajaan Kediri sehingga pengguna dapat merasakan suasana dalam runtuhnya kerajaan Kediri tersebut.

Pengembangan komik digital ini membutuhkan smartphone, dengan smartphone media komik media dapat digunakan dimana saja sehingga siswa merasa mudah melakukan dalam melakukan pembelajaran. Karena smartphone memiliki potensi dan pemanfaatan untuk menjadikan pembelajaran mobile learning peluang besar, karena smartphone dapat digunakan untuk menyimpan bahan pelajaran yang secara signifikan mengurangi beban berat yang dibahwa siswa dipunggung mereka (Kacetl \& Klímová, 2019). Ditambah dengan era digital sekarang guru dapat memanfaatkan pembelajaran dengan smartphone (Kustianingsari, 2015). Hal ini dipengaruhi karena banyak orang tak terkecuali siswa itu sendiri memiliki smartphone. Penelitian pengembangan komik digital ini memiliki kelebihan bisa digunakan dirumah untuk belajar mandi mengingat kondisi pandemi Covid - 19 sedang melanda negara, sehingga pembelajaran yang dilaksanakan dengan menggunakan daring. Komik digital ini akan membantu menumbuhkan minat baca sehingga siswa dapat mengerti nilai - nilai moral yang terjadi dalam komik tersebut (Fathoni et al., 2016).

\section{SIMPULAN}

Berdasarkan penelitian pengembangan komik digital sebagai media pembelajaran IPS materi runtuhnya kerajaan Kediri dapat disimpulkan bahwa media yang dikembangkan layak untuk digunakan dalam pembelajaran yang ada didalam kelas. Karena diperoleh dari hasil positif yang didapat dari ahli media, ahli materi dan diujicobakan ke lapangan kepada siswa. Berdasarkan hasil penelitian yang sudah dilakukan, bahwa komik digital dapat memberikan rasa kemudahan, kemenarikan dan motivasi pada siswa dalam proses pembelajaran dikelas. Terdapat beberapa kekurangan dari media yang dihasilkan ini seperti saran dari ahli media untuk memberikan credit title. Dan juga saran dari ahli materi untuk memberikan pesan moral pada komik digital tersebut.

\section{DAFTAR RUJUKAN}

Afandi, R. (2011). Integrasi Pendidikan Karakter dalam Pembelajaran IPS di Sekolah Dasar. PEDAGOGIA: Jurnal Pendidikan, 1(1), 85-98.

Afiqoh, N., Atmaja, H. T., \& Saraswati, U. (2018). Penanaman Nilai Kearifan Lokal dalam Pembelajaran Sejarah Pokok Bahasan Perkembangan Islam di Indonesia pada Siswa Kelas X IPS di SMA Negeri 1 Pamotan Tahun Ajaran 2017/2018. Indonesian Journal of History Education, 6(1), 42-53.

Amalia, M. S., Ulfa, S., \& Soepriyanto, Y. (2020). Multimedia Tutorial Berbasis Android untuk Memudahkan Siswa Memahami Materi Mengenal Notasi Balok Kelas X Seni Musik. Jurnal Kajian Teknologi Pendidikan, 3(1), 59-67. 
Ashri, N., \& Hasanah, L. (2015). Pengembangan Bahan Ajar IPA Terpadu pada Tema Energi dan Lingkungan. Prosiding Simposium Nasional Inovasi Dan Pembelajaran Sains, 469-472.

Azman, M. N. A., Azli, N. A., Mustapha, R., Balakrishnan, B., \& Isa, N. K. M. (2014). Penggunaan Alat Bantu Mengajar ke Atas Guru Pelatih bagi Topik Kerja Kayu, Paip dan Logam. Sains Humanika, 3(1).

Azmi, M. (2016). Pengembangan Mobile Learning Sebagai Alternatif Media Pembelajaran di Masa Depan. Prosiding Seminar Nasional Teknologi Pendidikan.

Chen, G. D., Fan, C. Y., Chang, C. K., Chang, Y. H., \& Chen, Y. H. (2018). Promoting autonomy and ownership in students studying English using digital comic performance-based learning. Educational Technology Research and Development, 66(4), 955-978.

Crompton, H., \& Burke, D. (2018). The use of mobile learning in higher education: A systematic review. Computers \& Education, 123, 53-64

Fathoni, K., Setiowati, Y., \& WS, L. P. (2016). Rancang Bangun Aplikasi Komik Digital Cerita Wayang Kulit sebagai Media Pembalajaran Budaya Jawa Berbasis Android. SCAN-Jurnal Teknologi Informasi Dan Komunikasi, 11(1), 51-58.

Gall, M. D., Gall, J. P., \& Borg, W. R. (2003). Educational Research: An Introduction. Pearson Education.

Herijanto, B. (2012). Pengembangan CD Interaktif Pembelajaran IPS Materi Bencana Alam. Journal of Educational Social Studies, 1(1).

Hutton, L., \& Hembacher, D. (2017). Create space for history-social science in elementary classrooms to foster content knowledge, inquiry, literacy, and citizenship. Social Studies Review, 56, 44-50.

Kacetl, J., \& Klímová, B. (2019). Use of smartphone applications in english language learning-A challenge for foreign language education. Education Sciences, 9(3), 179.

Kustianingsari, N. (2015). Pengembangan Media Komik Digital pada Mata Pelajaran Bahasa Indonesia Tema Lingkungan Sahabat Kita Materi Teks Cerita Manusia dan Lingkungan untuk Siswa Kelas V SDN Putat Jaya III/379 Surabaya. Jurnal Mahasiswa Teknologi Pendidikan, 6(2).

Martha, Z. D., Adi, E. P., \& Soepriyanto, Y. (2018). E-book berbasis Mobile learning. Jurnal Kajian Teknologi Pendidikan, 1(2), 109-114.

Mediawati, E. (2011). Pembelajaran Akuntansi Keuangan melalui Media Komik untuk Meningkatkan Prestasi Mahasiswa. Jurnal Penelitian Pendidikan, 12(1), 68-76.

Ntobuo, N. E., Arbie, A., \& Amali, L. N. (2018). The development of gravity comic learning media based on gorontalo culture. Jurnal Pendidikan IPA Indonesia, 7(2), 246-251.

Nugraha, M. (2018). Manajemen Kelas dalam Meningkatkan Proses Pembelajaran. Tarbawi: Jurnal Keilmuan Manajemen Pendidikan, 4(01), 27-44.

Nurmadiah, N. (2016). Media Pendidikan. Al-Afkar: Jurnal Keislaman \& Peradaban, 5(1).

Nurrita, T. (2018). Pengembangan Media Pembelajaran untuk Meningkatkan Hasil Belajar Siswa. MISYKAT: Jurnal Ilmu-Ilmu Al-Quran, Hadist, Syari'ah Dan Tarbiyah, 3(1), 171.

Patricia, F. D. (2018). Analisis Semiotika Komunikasi Visual Buku "Memahami Komik" Scott McCloud. Jurnal Studi Komunikasi, 2(2).

Putri, S. D., \& Citra, D. E. (2019). Problematika Guru dalam Menggunakan Media Pembelajaran pada Mata Pelajaran IPS di Madrasah Ibtidaiyah Darussalam kota Bengkulu. Indonesian Journal of Social Science Education (IJSSE), 1(1), 49-55. 
Ratnaningsih, S., \& Nastiti, G. (2018). Upaya Meningkatan Motivasi Belajar Siswa dengan menggunakan media gambar pada pembelajaran tematik di sekolah dasar. Al Ibtida: Jurnal Pendidikan Guru MI, 5(2), 275-286.

Ratnawati, E. (2016). Pentingnya Pembelajaran IPS Terpadu. Edueksos: Jurnal Pendidikan Sosial \& Ekonomi, 2(1).

Sihkabuden. (2011). Media Pembelajaran. Malang: FIP UM.

Siska, Y. (2016). Konsep Dasar IPS untuk SD/MI. Garudhawaca.

Sukmanasa, E., Windiyani, T., \& Novita, L. (2017). Pengembangan Media Pembelajaran Komik Digital Pada Mata Pelajaran Ilmu Pengetahuan Sosial Bagi Siswa Kelas V Sekolah Dasar di Kota Bogor. JPsd (Jurnal Pendidikan Sekolah Dasar), 3(2), 171-185.

Suwardi, I., \& Farnisa, R. (2018). Hubungan Peran Guru Dalam Proses Pembelajaran Terhadap Prestasi Belajar Siswa. Jurnal Gentala Pendidikan Dasar, 3(2), 181-202.

Tresnawati, D., Satria, E., \& Adinugraha, Y. (2016). Pengembangan Aplikasi Komik Hadits Berbasis Multimedia. Jurnal Algoritma, 13(1), 99-105.

Yunanto, H. Y., \& Heryanto, N. Y. (2021). Analisis Pendekatan Timeframing pada Komik Sejarah (Studi Kasus: Suryakarta). PROSIDING Konferensi Mahasiswa Desain Komunikasi Visual (KOMA DKV), 1(1), 309-314. 